\title{
Implementation of Islamic religious learning strategies in children with autism in Indonesia
}

\author{
Hanif Cahyo Adi K. Kistoro ${ }^{\mathrm{a}, \mathrm{b}}$, Badrun K. Kartowagiran ${ }^{\mathrm{b}}$, Eva L. Latipah ${ }^{\mathrm{c}}$, \\ Ngainun N. Naim ${ }^{d}$, Himawan P. Putranta ${ }^{\mathrm{e}}$ \\ a Ahmad Dahlan University - Faculty of Islamic Religion, Department of Islamic Religious \\ Education, Yogyakarta, Indonesia \\ ${ }^{b}$ Yogyakarta State University - Graduate School, Department of Educational Research and \\ Evaluation, Yogyakarta, Indonesia \\ ${ }^{c}$ Sunan Kalijaga State Islamic University - Faculty of Tarbiyah and Educational Sciences, \\ Department of Islamic Religious Education, Yogyakarta, Indonesia \\ ${ }^{d}$ Tulungagung State Islamic Institute - Faculty of Ushuluddin, Adab, and Da'wah, \\ Department of Aqidah and Islamic Philosophy, Tulungagung, Indonesia \\ e Yogyakarta State University - Graduate School, Department of Educational Sciences, \\ Concentration of Physics Education, Yogyakarta, Indonesia
}

Introduction. Important religious education is given to children with autism. Objective. This research aims to analyze teachers' experience in implementing Islamic religious learning strategies (IRLS) for children with autism. Methods. This research is qualitative research with a phenomenological approach. The participants were six Islamic religion teachers from two exceptional schools in Yogyakarta who were selected using a purposive sampling technique. In-depth interviews and observation methods were used in data collection techniques. The coding analysis method, with the stages of data organization, reading data, coding data, determining and connecting themes with descriptions, and interpreting data, was used for data analysis. Results. The research results found that IRLS for children with autism has three stages, namely planning, implementation, and evaluation. Planning is done to determine the preparation that must be done before the learning process. Learning implementation includes reading and writing as well as interpreting the material. The evaluation is carried out to determine the level of success of the learning process that has been carried out. The IRLS carried out by teachers include two-way communication, adequate experience, and innovation skills. Conclusion. The strategies are expected to be further enhanced to reduce constraints in learning.

Keywords: Autism, experience, Islam, teaching skills

Correspondence: Hanif Cahyo Adi Kistoro, hanif.kistoro@pai.uad.ac.id 


\section{Introduction}

Education has an important role in human life. Education is the right of every human being according to the Constitution of the Republic of Indonesia, which states that the state guarantees education for all Indonesian people. This means that every citizen has the right to receive proper education (Wahyuningsih, 2016). The basic concept of national education is to develop children's abilities systematically in the form of learning in both formal and informal schools. Practice indicates that many children have not received proper education. This is due to an individual's ability or lack of access to education. Limitations in individual abilities can be caused by the children's below-average intelligence or physical limitations so that they cannot participate in learning properly (Al-Elaimat et al., 2020; Dučić, 2017). The existence of a child's limited abilities will affect the child's ability to absorb the material cognitively, emotionally, and socially. This is the biggest obstacle for students, in addition to other obstacles, such as negative perceptions by the community regarding the condition of children with special needs. The society often underestimates children who experience this obstacle and often treats them differently both in daily interactions or providing opportunities in any aspect (Chen \& Peng, 2020). The existence of this situation causes problems in the world of education. On the one hand, education must be given to all people; on the other hand, some limitations become obstacles in the implementation of education.

The Law of the Republic of Indonesia Number 20 of 2003 clearly states that all citizens are entitled to the highest education possible. Citizens who have physical, emotional, mental, intellectual, and social limitations are also entitled to special education (Ministry of Education and Culture, 2014). Special education for children with developmental delays is explained as a form of education provided either in special schools or inclusive schools. This research will explain the implementation of education in special schools. Special schools also direct education for children who experience delays in obtaining the highest level of education (Robeyns, 2016). The obstacles often faced by teachers in special schools are related to internal and external factors. Internally, the ability of children with delays is a major issue. They are cognitively unable to accept subject matter quickly. Lack of emotional, mental, and social skills is another factor in learning constraints.

Apart from internal factors, several external factors arise in the implementation of education for children with delays. There are only few universities which offer degrees in special education. Furthermore, schools for children with special needs are also scarce. Meanwhile, many children need special schools, which causes an imbalance. Based on the data, there are sixtyseven special schools throughout the Yogyakarta region, nine of which are state schools and the rest are private schools, with a total student population of three thousand six hundred and eleven (Ministry of Education and Culture, 2017). 
The number of school principals and special school teachers is nine hundred and sixty-three people. There are ninety-seven religious education teachers in special schools, or about ten percent of the total number of teachers. This condition illustrates that especially in religious lessons with a limited number of teachers and a small number of teaching hours, namely four hours a week, schools face a serious problem in providing maximum religious subject matter. One way to overcome this problem is the fact that some schools provide extracurricular assistance to children for strengthening religious materials. This means that apart from formal schooling, children get religious material in class, but the teacher also provides additional material outside the classroom.

Another obstacle faced in inclusive schools is the assumption that children with developmental delays and children with typical development are mixed in the learning process (Gumiandari \& Nafi'a, 2020; McKee \& Gomez, 2020). Inclusive schools must provide assistance and special facilities to support the smooth process of education for children with developmental delays. The categories of children with developmental delays have their respective types. There are three categories of children with developmental delays, namely based on learning and ability disorders, behavioral disorders, and physical and multiple disorders. The first type includes children with special learning disabilities, slow learners, and children with special talents. The second type usually consists of children with autism, children with attention deficit hyperactivity disorder or attention deficit hyperactivity disorder (ADHD), indigo, anxiety. The third category is based on physical and multiple disorders, and includes children with visual impairment, hearing impairment, physical impairment, and multiple hearing impairment (Dunn et al., 2020).

Children with autism are children who have obstacles in interaction with others. Children with autism are not without the ability to communicate, it is just that they have limitations in the communication process (Carruthers et al., 2020). In general, children with autism tend to limit themselves and are more interested in their world, thereby ignoring social contact with the wider community. Therefore, parents have obligations and important roles in assisting their development at home (Rankin et al., 2019; Singh, 2015). In general, special schools organize education by mixing children who have a disorder in one class. This also applies to schools in general, the difference lies in special teachers in inclusive schools, their learning strategies, and the curriculum. The curriculum needs to be specifically designed (Zitter et al., 2016). Apart from the curriculum, the professionalism of a teacher is also needed in the learning process (Isbah, 2020; Moore \& Clarke, 2016). Teachers become the main source of knowledge for children with autism. The teacher must have a high level of creativity and be open and patient in carrying out the learning process.

Students with special needs certainly cannot receive learning perfectly. Thus, teachers have to be smart in making learning strategies that are easy to 
accept and fit the child's condition. Also, communication competence has an important role in the success of learning (Cook, 2016). Due to their limited abilities, these children also require repeated lessons. This is where teachers are required to remain patient in teaching until the child can absorb and understand the material being taught (Latipah et al., 2020). Apart from the general material, religious material as a process of character education is also very important for children with autism. Thus, religious education becomes mandatory material that must be given (Christian, 2018). Religious education is the main basis for developing abilities and strengthening the character of children. Of course, religious education is given following the beliefs of children or autistic students. Learning material also influences the teacher's methods and strategies used (Asrial et al., 2019). Islamic religious education is education that is carried out following Islamic teachings through guidance and care for students. This is done so that the child can understand, live, and practice the teachings of Islam that he/she has believed in as a whole, and make religious teachings a way of life. (Panjwani \& Revell, 2018). Furthermore, religious education, in particular, is a process of conveying knowledge and developing the basic potentials of children which are still hidden and which include faith or belief, knowledge, morality or morality and experience (Kistoro, 2014). In addition, religious values must be provided to all, both children with typical development and the ones with special needs (Latipah et al., 2019) to strengthen religious education in the family and community environment (Masduki et al., 2019).

Religious education is also intended to increase the spiritual potential and emotional intelligence, and to shape students to become human beings who believe in and fear God Almighty, and have a good character (Hadi, 2019; Kistoro, 2014). A noble character includes ethics, character, and morals as an embodiment of religious education. Increasing spiritual potential includes the practice, understanding, and inculcation of religious values, as well as the practice of these values in individual or collective community life (Kelleher et al., 2019). Increasing the potential and understanding of deep religious teachings that can affect the attitudes and behavior of individuals in everyday life is no exception for children with autism (Crawford Sullivan \& Aramini, 2019). Following these problems, in this research, the objectives to be achieved are to find out the implementation of methods and strategies in the learning process of religious education given to children with autism.

In inclusive schools, teachers, as one of the factors that influence the success of the learning process, are required to have a minimum standard of service competency. Competence that is considered adequate is a combination of pedagogic skills, professional skills, personality skills, and social skills (Brundiers \& Wiek, 2017). Nevertheless, in reality, the competencies of teachers in inclusive schools still tend to be below standard. This means that there is no difference between the proportion of students and the number of teachers (Basit 
\& Puspitarini, 2019). This condition affects the learning conducted. The teacher must make an appropriate strategy based on the desired learning outcomes and the student's ability to learn. The existence of this problem requires teachers to be more creative and innovative in the strategies implemented. Moreover, the ability of children with autism, in general, is very different from the ability of typically developing children. Teachers' experience in the learning implementation strategy will be revealed in this research. Realizing the importance and role of learning strategies in improving the quality of education, this study will specifically examine the learning strategies implemented by teachers in special schools and the obstacles they face based on the experiences of teachers in the learning process carried out.

\section{Methods}

\section{General background}

This type of research is qualitative research with a transcendental phenomenological approach (Moustakas, 1994). This research was conducted to explore more information about the experience of teachers in implementing learning for children with autism. Specifically, this research aims to gain a deep understanding of the strategies and ways of teaching used by teachers in inclusive schools and the types of competencies teachers must have. The research lasted for three months, from October to December 2019. This research is expected to be the basis for further research development.

\section{Participants}

The main data source or participants are teachers in inclusive schools in Yogyakarta. The participants in this research were six teachers from two special schools in Yogyakarta, namely the initials SLB KY and SKA BA. The purpose of a disguised identity is to protect and maintain the privacy of the subject. The selection of six participants was based on research design according to Creswell and Creswell (2017) that exploratory phenomena can be carried out on heterogeneous participants between three to fifteen people. The procedure for collecting data involved the stages of requesting approval from the school agency and then contacting the teachers planned to be involved in this research. Data retrieval was done by a purposive sampling technique, where researchers have certain criteria of participants (Creswell \& Creswell, 2017). Criteria for participants were teachers in special schools for children with developmental delays, with an integrated method, considered to be exceptional reference schools in Yogyakarta. The characteristics of the participants involved in this research can be shown in Table 1 below. 


\section{Table 1}

Participants Profile from Two Inclusive Schools

\begin{tabular}{cccccccccc}
\hline \multirow{2}{*}{ Special School } & \multicolumn{2}{c}{$\begin{array}{c}\text { Primary } \\
\text { School }\end{array}$} & \multicolumn{2}{c}{$\begin{array}{c}\text { Junior } \\
\text { High School }\end{array}$} & \multirow{2}{*}{ Age } & Lesson & Graduates & Total \\
\cline { 2 - 6 } & Male & Female & Male & Female & & & & \\
\hline SLB KY & - & 2 & 1 & - & $30-35$ & Religion & Bachelor & 3 \\
SLB BA & - & 2 & - & 1 & $35-45$ & Religion & Bachelor & 3 \\
\hline
\end{tabular}

\section{Instruments and procedures}

The research data collection was carried out by in-depth interviews and observation techniques. The duration of the interview was around 60 minutes. The interviews were conducted at school with consideration of getting good quality interviews. The interview questions were open and general, arranged in the form of an interview protocol (Creswell \& Creswell, 2017). The atmosphere was as comfortable as possible so that the participants could answer every question freely (Moustakas, 1994). Also, several observations of the learning process were also made and the results of the learning strategies were observed in the form of guidelines or observation rubrics. Furthermore, the research procedure began with the initial observation stage as one of the data collection techniques to determine the learning system that was carried out. Initial observations were made by researchers to determine the condition of the subjects taught in special schools. Observations were made three times in different periods, namely at the beginning of learning, during the implementation of learning, and at the end of learning, according to the protocol in observation, using the observation checklist about the learning process from beginning to end. The next stage were in-depth interviews with the participants to get more information related to the learning strategies used, starting from the initial process/preparation of learning, implementation of learning, and evaluation of learning that was carried out.

The interviews were conducted as part of data collection in this study. The researchers conducted the interviews by not directing the subjects to answer what they wanted. The subjects answered freely and in accordance with what was experienced. The questions in the interview covered the following major themes, namely the teacher's level of education, first-time teaching experience, subjects being taught, teaching strategies, and obstacles and support in learning. Examples of questions asked in the interview included the teacher's profile, when they started teaching at special schools, what competencies were required, what strategies they applied, what constraints and support were obtained when implementing learning. Data collection procedure began by asking the research subject, in this case the teacher, for consent to participate in the interview. The target number of participants was originally eight teachers. However, two teachers did not wish to be interviewed for personal reasons. Teachers who were willing to be interviewed in the form of audio recordings signed their consent in the written form provided by the author. The process of collecting 
interview data was given a special code according to the initials of the research subject. This was agreed by the researchers as part of writing ethics by not including the real names of the participants.

The procedure of implementing data collection was carried out after obtaining the data collection permit from the school principal. Based on the results of in-depth interviews that were conducted, six participants, out of the planned eight, were included. The other four participants could not provide data because they could not be interviewed and it coincided with assignments at school. Recording devices recorded all interviews for forty-five to sixty minutes. To get quality results, the researchers conducted the interview at school so that the participants were comfortable answering and providing information. After the data was obtained, it was translated or transcribed verbatim or by verbatim techniques. The interview data transcript was then coded.

\section{Data analysis}

Data analysis used coding techniques in which the research data are arranged into five to seven themes (Creswell \& Creswell, 2017). The analysis model used data analysis developed by Creswell with the stages of data organization, reading all data, coding data, determining themes and descriptions, linking themes and descriptions, and interpreting the meaning obtained. The first stage was obtaining raw data through interviews and observations with the participants. After raw data was obtained, the next step was to organize the data from the participants. The next stage was to read all the data obtained by interviews and observations with the participants carefully. After the data was read as a whole, it was then coded for each part. This data coding was done to classify similar responses from each participant. The next stage was to determine and link the appropriate theme and description from each interview and observation result given by the participants. After these stages were carried out, the next stage was to interpret each theme and description that was linked. Systematically, the data analysis model in this research is shown in Figure 1 below.

Explanation of meaning or essence description is an important point in qualitative research that uses a phenomenological approach (Moustakas, 1994). The essence of the description is something that is being experienced and how the individual, in this case the teacher, deals with this experience. Data reduction based on participant experience becomes an important part of data analysis. To get quality data, several stages are carried out, namely classifying important statements in the main theme, and describing the meaning of the experience of the phenomenon as a whole. The data analysis procedure in this research began by converting the recorded sound from the interview into a transcript so that various pieces of information could be easily examined. The researchers carefully read the interview transcript several times. 


\section{Figure 1}

Model of Research Data Analysis

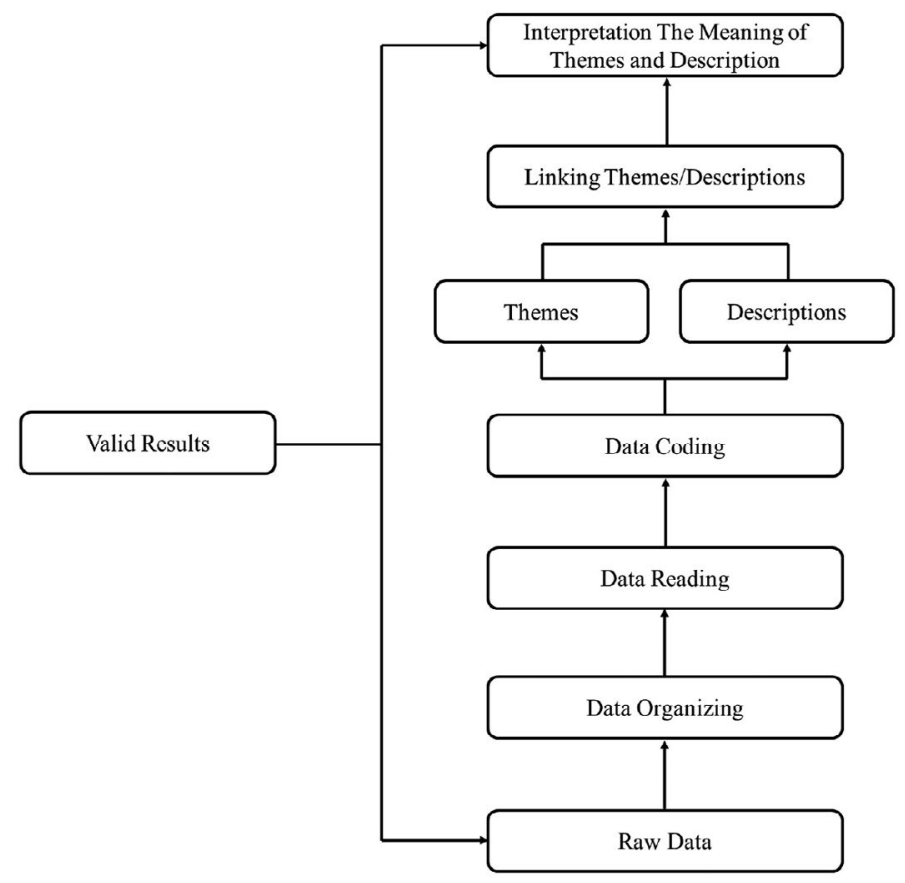

Along with this process, the researchers also chose important information from the transcript to be an important statement. Important statements identified by the researchers were further grouped into central themes. This important statement and the central theme were then used to make a texture description, which is a description of what the participants experienced. In order to make structural descriptions, namely descriptions of how the participants experienced the phenomenon, the researchers also used important statements and central themes. The final step in the data analysis procedure was writing the essence of all phenomena experienced by the participants. The essence description is a combination of texture and structural description that reveals the essence of the phenomenon experienced by the participants.

\section{Results and discussion}

Based on the results of research and discussion, important themes related to religious learning strategies for children with autism can be compiled. There are four main themes in this study, namely the competence of religious education for children with autism, the competence of learning outcomes for children with autism, the strategies and implementation of learning carried out, the factors that support and hinder the implementation of learning strategies. 


\section{Knowledge competence for children with autism}

Education for children with autism is certainly a little different from the education provided to children with typical development. In theory, children with autism have several problems in the learning process. Cognitive abilities, language and communication skills, and psychomotor abilities are the main obstacles. Autism itself is a term used for a condition that is generally considered a developmental disorder for certain children (Robeyns, 2016). Autism is a complex neurological disorder characterized by limited communication skills, social anxiety, and typical behavior (Sigmon et al., 2016). Almost all children with autism have similar characteristics, such as being alone, doing a complicated and repetitive routine called stimming. The most common examples are rocking, moving independently, repeating words, piling up objects, and even banging one's head (Jones et al., 2019). The existence of common characteristics and traits such as those experienced by children with autism certainly makes the teacher identify the methods and strategies that will be used in the learning process. Therefore, it can be understood that the ability of teachers to teach children with autism must be balanced with skills in communication and good creativity.

The education system in the Republic of Indonesia has the aim to increase the potential and talents of all citizens through structured and sustainable education (Republic of Indonesia, 2003). To achieve this, it is necessary to have teachers who have adequate competence. There are four competencies that a teacher must have in carrying out the learning process, namely pedagogical competence, personality competence, professional competence, and social competence (Republic of Indonesia, 2005). Pedagogic competence is the teacher's ability to carry out the learning process based on existing theories. Personality competence is the teacher's ability to be a role model for students by reflecting a good personality, dignified, and noble so that it becomes a role model for students.

The purpose of providing contemporary religious education according to Zidny and others (Zidny et al., 2020), is not only to change the socio-cultural and knowledge base of students but also to be able to resolve the moral and ethical problems of modern science. The process in religious education is the cultivation of faith and piety in each individual, and shaping human morals so that the individual has a noble personality and character according to the teachings of Islam. Inclusion teachers who teach children with developmental delays are one of the important elements of success in character education (Ergin \& Bakkaloğlu, 2019; Putranta \& Jumadi, 2019). Therefore, inclusive teachers must be equipped with comprehensive abilities such as pedagogical, personal, professional, and social competencies. This competency also affects the use of methods and strategies in implementing the learning process. The competency that children with autism are expected to have, in general, is to have a minimum 
standard in learning which is reading and writing. There is hope that children are also able to understand and implement basic learning outcomes in religious education such as reading the Al-Qur'an and performing prayers.

\section{Competence of children with autism and learning outcomes}

Learning is generally defined as a process of learning and teaching in which there are interactions of two parties in the exchange of knowledge. Teachers are not the only source of knowledge, but students can also be used as information providers (Muhtar \& Dallyono, 2020). In the learning process, a teacher must understand his/her position, understand the nature of teaching and its application. Good teaching will produce good output too. This is similar in teaching children with autism. Although they have limitations, it is expected that the appropriate methods and strategies can make them have the expected competence. The basic competencies desired in this research are specifically students' abilities to read, write, and perform routine worship activities such as prayer. This was confirmed by one of the teachers in recounting their experiences during the interview, "After the morning greetings, students perform the dhuha prayer in congregation. Students are guided in prayer, because students still have not memorized the order of ablution. I also guide students in praying. Sometimes the students just move around and we read prayers to God. They are enthusiastic about this routine. After prayers we read the Quran together.".

\section{Implementation of Islamic religious learning strategies in children with autism}

Several stages need to be done before the implementation of learning. These stages include planning, implementation, and evaluation of learning. Planning begins with selecting teachers who have the potential to teach in inclusive classes. Teachers, who have competence in teaching, can provide effective teaching (Roose et al., 2019). Based on the results of the interview two teachers explained that "There are only two teachers here who are graduates of special inclusive schools namely me NH and SF. Nevertheless, other teachers, although not special graduates have long experience because they often attend training, workshops, and the like. Usually, those who have participated in training and workshops will get a certificate of teaching competence for children with developmental delays".

The explanation implies that among teachers who work in inclusive schools, two people are graduates of tertiary institutions majoring in special education, and the rest are not special education graduates. However, all of them can teach by meeting the minimum standard requirements. In the next planning stage, teachers will usually modify the existing curriculum to make it suitable and appropriate for students who have limitations. This is because the ability of each child is different. Planning in this stage will also affect the methods that 
will be used when the learning process takes place. Another tool that needs to be prepared in planning is a special record of the progress of each child in the form of an IEP (Individualized Education Program), which is an individual learning program used for each student they support. Teachers are required to understand the characteristics of the students they support, making it easier to provide learning with regard to the characteristics of these students.

Learning media are also included in the planning list. In general, the media used to educate children with autism are images or visuals. The teacher prepares the media that will be used in the learning process in the form of drawings, learning books, paper media, and colored pencils (usually to color the images related to the theme) and present real examples of the themes to be discussed. This is consistent with the explanation of one of the teachers who said that "Teachers here usually have their methods of teaching. Some prepare drawing books, colored paper, colored pencils, and others. Some make interesting toys. This is intended to attract the attention of children because usually, they tend to have low concentration power". Based on observations, in teaching certain themes such as commendable moral themes, the teacher prepares a picture of a child helping parents, and then students are asked to color the drawing with colored pencils that are deliberately not yet sharpened. The teacher then directs the students to sharpen the colored pencils so that they can be used for coloring. In the end, the teacher asks students to throw away the pencil sharpener in the trash.

Teachers who teach in special schools are required to independently make props in strengthening learning strategies. The teacher will make media that can be seen, touched, or even practiced by students. The existence of this teaching aid is very helpful for teachers in explaining the material to children. After that, the teacher explains that what the students have done is an example of good behavior. Religious learning is closely related to communication, especially intrapersonal communication. Intrapersonal communication in learning is directed at children's communication with God. The application of intrapersonal communication in inclusive schools is in the form of prayer, worship, and self-introspection. Islamic religion teachers every day invite students to communicate with the creatorby conducting Dhuha prayer before the start of learning. Furthermore, some teachers participate in conducting the Dhuha prayer and others guide their students in the implementation of the Dhuha prayer. As is known, children with autism must always be given guidance, direction, and examples. This practice is indirectly used at the same time to instill character education and form good morals for students. The habit that is carried out routinely turns out to foster the ability of children in terms of worship.

This was acknowledged by one of the religious teachers who explained the condition of the children "Even children go to the mosque on their initiative without instructions from the teacher. However, many have not been able to 
carry out the Dhuha prayer correctly. Sometimes, we deliberately want to see how sensitive they are, so we deliberately do not give guidance. Then after they go to the mosque, we are happy they have a good initiative and we go to the mosque in part to guide the prayers in part to pray with the children. They have even been able to become priests, with the abilities they have". Another teacher added, "Students are still guided in praying, but they only follow the prayer movements that I do. Even so, students like the routine they do together with the teachers.".

Before the learning process begins, students are accustomed to praying. After praying, the students then read the Iqra' according to their respective levels. Iqra reading 'also still needs to be guided by the teacher, usually by writing Hijaiyah letters on large paper. In the implementation of learning, there are two general stages carried out. First, students are asked to read and write and then the teacher explains. In the reading process, students are given a book that contains certain material with regard to the theme to be discussed and then asked to read it. The teacher will read for students who are not fluent in reading, as shown in the results of observations made by the researchers in Figure 2 below.

\section{Figure 2}

\section{Autistic Students Reading Iqra (Documentation at SLB BA Yogyakarta)}

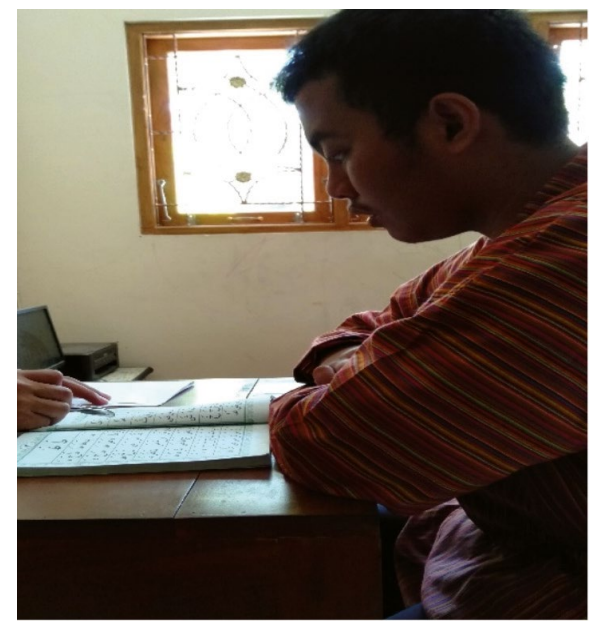

Note. There is consent between SLB BA Yogyakarta, students, and parents to publish the photo.

After the reading activity, it is proceeded with writing the material that has been read in a special notebook prepared by the teacher for each student. The goal is for the students to memorize the material that has been read. Generally, the writing process takes quite a long time, so progress in this ability is usually a bit slower than expected. This is possibly because students have to do two things - remember the letters and write them, while their ability to do that is 
limited. After finishing writing, the teacher's role begins. The teacher explains the material that has been read and written by students. The explanation also lasts quite a long time, because very simple language must be used so as to be understood by students, as shown in the results of observations made by the researchers in Figure 3 below.

\section{Figure 3}

The Process of Explaining Islamic Religious Materials (Documentation at SLB KY Yogyakarta)

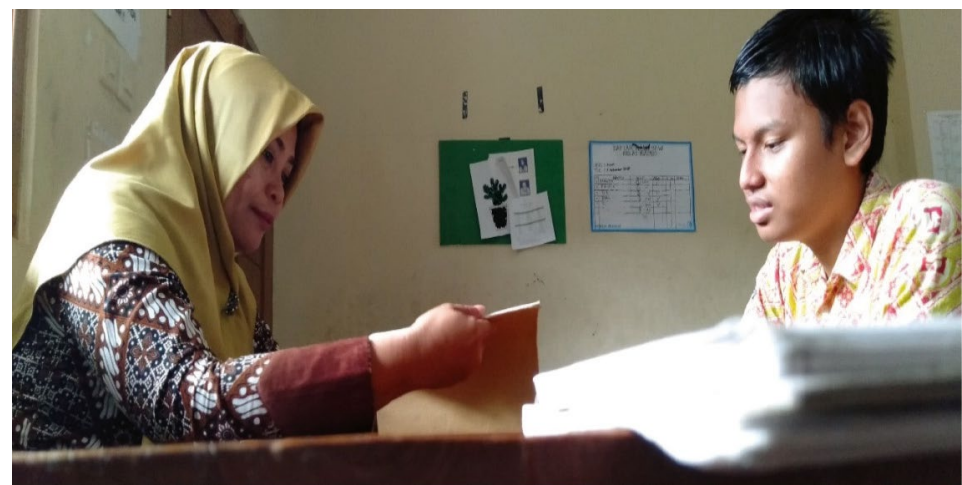

Note. There is consent between SLB KY Yogyakarta, students, and parents to publish the photo.

In the second learning process, after reading, writing, and explaining, there is a repetition of material. In the observations made, before learning a new theme, the teacher repeats previously learnt religious material. This is done by asking questions related to past themes. If the students can answer the questions, it means they understand and remember the past material. If the students are not able to answer the given questions, then learning a new theme will not be implemented, but will be replaced to repeat the material from the last meeting. One indicator of the success of learning can be seen in the Dhuha prayer activities, where students can carry out the Dhuha prayer at the usual time without getting directions or instructions. At the evaluation stage, , tests are conducted in the form of questions and answers to determine the level of students' understanding of the material. The questions and answers refer to the material that has been studied. In asking questions, the teacher must use simple and not convoluted question words, for example, "Let me ask, what did you read?". The question must also be asked with expressions and body gestures that make students remember what was learned. The self-introspection session was also conducted as a form of learning evaluation.

At the time of observation, several incidents were found, for example when a student borrowed stationery from his friend and then returned it without saying thanks, the teacher immediately seated the student and gave advice 
related to the courtesy of borrowing other people's things simply. "Did you borrow your friend's eraser? Did you say thank you yet? Earlier your writing was wrong, after that you borrowed your friend's eraser, now the writing is correct. What should you do?". Positive responses from students include looking down as if evaluating themselves. Although it looks simple, for children with autism this is a good achievement and is one of the indicators of religious education learning. Based on the explanation of the research results above, there are still several weaknesses related to the media used in the implementation of learning in special schools. Now the teachers independently make simple teaching aids. This is of course a serious problem for the future, because with the improvement in technology, a visual aid can be made in the form of an audio-visual program application that can be displayed and practiced optimally. There are several suggestions for developing religious learning methods for children with autism in the future, regarding the provision of more complete audio-visual media which will make it easier to provide learning materials. This media can be in the form of an application that can be used by all teachers who teach children with autism (Brodhead et al., 2018). In addition, teachers also need to be equipped with more skills in the use of instructional media either through training or workshops.

\section{Supporting and constraint factors of Islamic religious learning in children with autism}

The implementation of learning in schools certainly cannot be separated from many factors, both those that support success or which become obstacles in its implementation. The main supporting factor in learning Islam in children with autism in inclusive schools is the availability of teachers who already have minimum service standards. These competent teachers with all their abilities in the pedagogical, personal, social, and professional aspects can provide materials and practices that are appropriate or close to the expected curriculum. According to information from experienced teachers, "A teacher should ideally be able to do everything, both to teach the material, and be an example for students. My principle in teaching students is to know their abilities so that they can determine teaching strategies in optimizing students' abilities". The teacher factor is the main factor in supporting the success of the learning implementation, especially religious education materials for children with autism.

Other teacher teaching experiences show, "The professionalism of teachers in our school is still below standard. This is because not all teachers have the ability to teach students in inclusive schools". In theory, many experts have agreed that a child with autism has a disorder in the brain. The occurrence of these disorders causes children to be less sensitive to the environment and absorbed in their world. According to Sathyanesan and others (Sathyanesan et al., 2019) abnormalities in the head organs, especially the cerebellum will 
influence sensory processes, memory, thinking, learning, language, and attention processes. Thus, the main factor inhibiting the learning process in children with autism is the limited ability of the child itself. The existence of these limitations then causes children with autism to lack focus. The teacher must have a strategy to be able to make children with autism focus on learning. Teachers use a unique strategy so that their students can focus on learning. If the strategy used by one teacher is applied to other students, it will not have any effect. Therefore, it can be concluded that the student will obey the command if he/she already knows who the other person is and matches the strategy used.

In addition to the supporting factors, the implementation of learning in special schools also has inhibiting factors. According to the research results, several inhibiting factors arise, namely the lack of adequate equipment, limited use of technology as part of the learning media, and the lack of in-depth knowledge of special learning strategies in special schools. Communication can also be an obstacle in the implementation of learning in autistic students. Based on the experience of the teachers, learning with classical models or group learning is not effective. This is due to the variety of abilities of each student, and also the variety of ways to communicate. Some students initially focus and then get bored, while some are preoccupied with their world, running and laughing without caring about learning. This opinion is supported by the teacher's statement in the interview that, "Children with autism tend to have different behaviors, they have difficulty communicating and interacting, so teachers must be able to follow their desires in the form of mentoring and continue to carry out communication so as not to lose focus". The communication model in learning in children with autism looks a little complicated because most children with autism are slow in their speech and language development. Sometimes the ability to speak is developed in children with autism, however, they are not able to apply it to communicate and interact with others.

The communication model that is suitable for children with autism is presenting real examples in the learning process. That is because children with autism cannot understand something abstract or unclear. Therefore, almost all teachers who teach children with autism always present a real example in every learning material. An effective communication model for children with autism is exclusively and intensively done. Exclusive means that communication is carried out specifically, where the teacher and students are in the same room and do not involve many parties. Whereas intensive means that the communication carried out in learning for children with autism must be repeated. Repeating the material that has been delivered will make students understand better, but of course, they must use interesting methods so that the communicant does not feel bored. This is where the role of a special teacher for children with autism is seen.

Two-way communication with a face-to-face model is where one teacher only communicates with one or two students. This is done so that the material 
delivered is easier to understand. Factors that inhibit further learning externally are the lack of school facilities (media) in learning. In inclusive schools, adequate facilities are needed to support the success of the learning process. In the inclusive school that were the subject of this research, the facilities were not yet widely available, but teachers usually had the creativity to get around this deficiency. For example, the teacher uses direct practice in religious learning material. However, more complete facilities and supported by teacher creativity would make learning more successful. In general, there are supporting and inhibiting factors in the process of learning religion for children with autism. Among the supporting factors is the competence of the teacher to use interesting learning methods through drawing and coloring media as well as to provide intense reading practice to children with autism (Chung \& Ghinea, 2020). On the other hand, some problems arise because the teachers have to prepare the material by themselves with regard to what should be taught. Not all teachers have competence in terms of creativity and innovation in making learning media (Festiyed \& Iswari, 2018).

\section{Research limitations}

Many limitations exist in this study. Among the limitations experienced by the researchers is the number of participants due to the unwillingness of the prospective participants related to privacy. Future participants can also include students, parents of students, or the surrounding community. The instruments used have not obtained detailed information that can explain the results from other perspectives. To obtain more complete data, observations can be further developed in the forms of observation and length of observation.

\section{Conclusions and recommendations}

Based on the results of the research, it can be concluded that the strategy and implementation of religious learning in inclusive schools is going well. This is evident from several indicators of student success in absorbing and receiving the subject matter. The ability of students to read the letters of the Al-Qur'an can already be achieved. Students also already have writing skills, although not as expected. The habit of performing prayers has also been ingrained in the hearts of children with autism, so they already have good habits in worshiping, for example performing Dhuha Prayers. With regard to specific themes based on teachers' experience, there are several stages in the strategy and application of religious learning for children with autism, namely planning, implementation, and evaluation of learning outcomes.

The results also show that in the implementation of learning, two-way communication strategies, adequate experience, teaching skills, creativity, and teacher innovation skills are competencies that teachers must have, especially in 
inclusive schools. This competency component is important for teachers before entering inclusive schools. The success of character education, especially for children with autism, requires strong collaboration within the environment, namely schools and teachers. School policies can take the form of curriculum, infrastructure, and facilities.

\section{Acknowledgements}

We would like to thank the participants who contributed to this research. We also thank fellow researchers who supported this research.

\section{References}

Al-Elaimat, A., Adheisat, M., \& Alomyan, H. (2020). The relationship between parenting styles and emotional intelligence of kindergarten children. Early Child Development and Care, 190(4), 478-488. https://doi.org/10.1080/03004430.2018.1479403

Asrial, A., Syahrial, S., Kurniawan, D. A., Subandiyo, M., \& Amalina, N. (2019). Exploring obstacles in language learning among prospective primary school teachers. International Journal of Evaluation and Research in Education, 8(2), 249-254. https://doi.org/10.11591/ijere.v8i2.16700

Basit, A., \& Puspitarini, R. C. (2019). Extension of digital media to strengthen learning outcomes with an online approach in inclusive school students. Journal of Development Research, 3(2), 43-51. https://doi.org/10.28926/jdr.v3i2.80

Brodhead, M. T., Courtney, W. T., \& Thaxton, J. R. (2018). Using activity schedules to promote varied application use in children with autism. Journal of Applied Behavior Analysis, 5l(1), 80-86. https://doi.org/10.1002/jaba.435

Brundiers, K., \& Wiek, A. (2017). Beyond interpersonal competence: Teaching and learning professional skills in sustainability. Education Sciences, 7(1), Article 39. https://doi.org/10.3390/educsci7010039

Carruthers, S., Pickles, A., Slonims, V., Howlin, P., \& Charman, T. (2020). Beyond intervention into daily life: A systematic review of generalization following social communication interventions for young children with autism. Autism Research, 13(4), 506-522. https://doi.org/10.1002/aur.2264

Chen, H., \& Peng, Z. (2020). Discontinuous learning through destructive experiences: A 'change' approach to catastrophe education in eco-pedagogy. Educational Philosophy and Theory, 52(13), 1409-1420. https://doi.org/10.1080/00131857.2020.1798756

Christian, S. M. (2018). Autism in international relations: A critical assessment of International Relations' autism metaphors. European Journal of International Relations, 24(2), 464-488. https://doi.org/10.1177/1354066117698030

Chung, S. J., \& Ghinea, G. (2020). Towards developing digital interventions supporting the empathic ability for children with an autism spectrum disorder. Universal Access in the Information Society, 8(2), 1-20. https://doi.org/10.1007/s10209-020-00778-9

Cook, J. (2016). From movement kinematics to social cognition: The case of autism. Philosophical Transactions of the Royal Society B: Biological Sciences, 371(1693), Article 20150372. https://doi.org/10.1098/rstb.2015.0372

Crawford Sullivan, S., \& Aramini, V. (2019). Religion and positive youth development: Challenges for children and youth with an autism spectrum disorder. Religions, 10(10), Article 540. https://doi.org/10.3390/rel10100540 
Creswell, J. W., \& Creswell, J. D. (2017). Research design: Qualitative, quantitative, and mixed methods approach. Sage publications.

Dučić, B. (2017). The relation between working memory and self-control capacity in participants with mild intellectual disability. Specijalna edukacija i rehabilitacija, 16(1), 55-72. https://doi.org/10.5937/specedreh16-12656

Dunn, K., Rydzewska, E., Fleming, M., \& Cooper, S. A. (2020). Prevalence of mental health conditions, sensory impairments, and physical disability in people with cooccurring intellectual disabilities and autism compared with other people: A crosssectional total population study in Scotland. BMJ Open, 10(4), Article e035280. https://doi.org/10.1136/bmjopen-2019-035280

Ergin, E., \& Bakkaloğlu, H. (2019). Examination of in-classroom transitions in inclusive preschool classrooms. Early Child Development and Care, 189(5), 820-834. https://doi.org/10.1080/03004430.2017.1345891

Festiyed, F., \& Iswari, M. (2018). The in-deep study problems organizers inclusive education of medium school in learning science in Padang. Journal of ICSAR, 2(2), 112-119. https://doi.org/10.17977/um005v2i22018p112

Gumiandari, S., \& Nafi'a, I. (2020). The role of Cirebon women Ulama in countering religious radicalism. QIJIS (Qudus International Journal of Islamic Studies), 8(1), 33-64. https://doi.org/10.21043/qijis.v8i1.6430

Hadi, N. (2019). Concept of educational values for Tauhid nation education system perspective. Indonesian Journal of Islamic Education Studies (IJIES), 2(1), 1-16. https://doi.org/10.33367/ijies.v2i1.652

Isbah, M. F. (2020). Pesantren in the changing Indonesian context: History and current developments. QIJIS (Qudus International Journal of Islamic Studies), 8(1), 65-106. https://doi.org/10.21043/qijis.v8i1.5629

Jones, A. E., Henzi, S. P., \& Barrett, L. (2019). A natural history of repetition. Journal of Montessori Research, 5(2), 15-44. https://doi.org/10.17161/jomr.v5i2.7407

Kelleher, C., N. Wilson, H., Macdonald, E. K., \& Peppard, J. (2019). The score is not the music: Integrating experience and practice perspectives on value co-creation in collective consumption contexts. Journal of Service Research, 22(2), 120-138. https://doi.org/10.1177/1094670519827384

Kistoro, H. C. A. (2014). Kecerdasan emosional dalam pendidikan Islam [Emotional intelligence in Islamic education]. Jurnal Pendidikan Agama Islam, 11(1), 1-18. https://doi.org/10.14421/jpai.2014.111-01

Latipah, E., Kistoro, H. C. A., \& Khairunnisa, I. (2020). Scientific attitudes in Islamic education learning: Relationship and the role of self-efficacy and social support. Edukasia: Jurnal Penelitian Pendidikan Islam, 15(1), 37-56. https://doi.org/10.21043/edukasia.v15i1.7364

Latipah, E., Kistoro, H. C. A., Hasanah, F. F., \& Putranta, H. (2020). Elaborating motive and psychological impact of sharenting in millennial parents. Universal Journal of Educational Research, 8(10), 4807-4817. https://doi.org/10.13189/ujer.2020.081052

Masduki, Y., Kistoro, H. C. A., Ru'ya, S., Sutarman, S., \& Sukirman, S. (2020). Strengthening religious education for family resilience in Yogyakarta Muslim minorities. Conciencia, 20(1), 28-39. https://doi.org/10.19109/conciencia.v20i1.5686

McKee, A., \& Gomez, A. S. (2020). Increasing inclusive education through a learning center model: A California approach. Journal of Education and Development, 4(1), 43. https://doi.org/10.20849/jed.v4i1.705

Ministry of Education and Culture. (2014). Peraturan Menteri Pendidikan dan Kebudayaan Republik Indonesia Nomor 157, Tahun 2014 tentang Kurikulum Pendidikan Khusus [Regulation of the Minister of Education and Culture of the Republic of Indonesia 
Number 157 of 2014 concerning Special Education Curriculum]. https://jdih. kemdikbud.go.id/arsip/Permendikbud\%20Nomor\%20157\%20Tahun\%202014.pdf

Ministry of Education and Culture. (2017). Statistik Sekolah Luar Biasa (SLB) 2016/2017

[Statistics for Special Schools (SLB) 2016/2017]. http://publikasi.data.kemdikbud. go.id/uploadDir/isi_F1E928A3-A219-43F7-88D5-14CDB42F86DE_.pdf

Moore, A., \& Clarke, M. (2016). 'Cruel optimism': Teacher attachment to professionalism in an era of performativity. Journal of Education Policy, 31(5), 666-677. https://doi.org/10.1080/02680939.2016.1160293

Moustakas, C. (1994). Phenomenological research methods. Sage publications.

Muhtar, T., \& Dallyono, R. (2020). Character education from the perspectives of elementary school physical education teachers. Jurnal Cakrawala Pendidikan, 39(2), 395-408. https://doi.org/10.21831/cp.v39i2.30647

Panjwani, F., \& Revell, L. (2018). Religious education and hermeneutics: the case of teaching about Islam. British Journal of Religious Education, 40(3), 268-276. https://doi.org/10.1080/01416200.2018.1493269

Putranta, H., \& Jumadi, J. (2019). Physics teacher efforts of Islamic high school in Yogyakarta to minimize students' anxiety when facing the assessment of physics learning outcomes. Journal for the Education of Gifted Young Scientists, 7(2), 119-136. https://doi.org/10.17478/jegys.552091

Rankin, J. A., Paisley, C. A., Tomeny, T. S., \& Eldred, S. W. (2019). Fathers of youth with autism spectrum disorder: A systematic review of the impact of fathers' involvement on youth, families, and intervention. Clinical Child and Family Psychology Review, 22(4), 458-477. https://doi.org/10.1007/s10567-019-00294-0

Republic of Indonesia. (2003). Undang-Undang Republik Indonesia Nomor 20, Tahun 2003, tentang Sistem Pendidikan Nasional [Constitution of the Republic of Indonesia Number 20, 2003, concerning the National Education System]. https:// pmpk.kemdikbud.go.id/wp-content/uploads/2020/10/Undang-Undang-Nomor-20Tahun-2003-tentang-Sistem-Pendidikan-Nasional.pdf

Republic of Indonesia. (2005). Undang-Undang Republik Indonesia Nomor 14, Tahun 2005, tentang Guru dan Dosen [Constitution of the Republic of Indonesia Number 14, 2005, concerning the Teachers and Lecturers.]. https://luk.staff.ugm.ac.id/atur/ UU14-2005GuruDosen.pdf

Robeyns, I. (2016). Conceptualizing well-being for autistic persons. Journal of Medical Ethics, 42(6), 383-390. https://doi.org/10.1136/medethics-2016-103508

Roose, I., Vantieghem, W., Vanderlinde, R., \& Van Avermaet, P. (2019). Beliefs as filters for comparing inclusive classroom situations. Connecting teachers' beliefs about teaching diverse learners to their noticing of inclusive classroom characteristics in videoclips. Contemporary Educational Psychology, 56, 140-151. https://doi.org/10.1016/j.cedpsych.2019.01.002

Sathyanesan, A., Zhou, J., Scafidi, J., Heck, D. H., Sillitoe, R. V., \& Gallo, V. (2019). Emerging connections between cerebellar development, behavior, and complex brain disorders. Nature Reviews Neuroscience, 20(5), 298-313. https://doi.org/10.1038/s41583-019-0152-2

Sigmon, M. L., Tackett, M. E., \& Azano, A. P. (2016). Using children's picture books about autism as resources in inclusive classrooms. The Reading Teacher, 70(1), 111-117. https://doi.org/10.1002/trtr.1473

Singh, J. S. (2015). Narratives of participation in autism genetics research. Science, Technology, \& Human Values, 40(2), 227-249. https://doi.org/10.1177/0162243914542162 
Wahyuningsih, S. (2016). Inclusive education for persons with disabilities: The Islamic perspective. QIJIS (Qudus International Journal of Islamic Studies), 4(1), 1-18. https://doi.org/10.21043/qijis.v4i1.1547

Zidny, R., Sjöström, J., \& Eilks, I. (2020). A multi-perspective reflection on how indigenous knowledge and related ideas can improve science education for sustainability. Science \& Education, 29(1), 145-185. https://doi.org/10.1007/s11191-019-00100-x

Zitter, I., Hoeve, A., \& de Bruijn, E. (2016). A design perspective on the school-work boundary: A hybrid curriculum model. Vocations and Learning, 9(1), 111-131. https://doi.org/10.1007/s12186-016-9150-y

\title{
Primena islamskih religijskih strategija učenja kod dece sa autizmom u Indoneziji
}

\author{
Hanif Cahyo Adi K. Kistoro ${ }^{\mathrm{a}, \mathrm{b}}$, Badrun K. Kartowagiran ${ }^{\mathrm{b}}$, Eva L. Latipah ${ }^{\mathrm{c}}$, \\ Ngainun N. Naim ${ }^{\text {, }}$, Himawan P. Putranta ${ }^{\mathrm{e}}$ \\ ${ }^{a}$ Univerzitet Ahmad Dahlan - Fakultet islamske religije, Katedra za islamsko versko \\ obrazovanje, Jogjakarta, Indonezija \\ ${ }^{b}$ Državni univerzitet u Jogjakarti - Poslediplomske studije, Katedra za obrazovna \\ istraživanja i evaluaciju, Jogjakarta, Indonezija \\ ${ }^{c}$ Državni islamski univerzitet Sunan Kalijaga - Fakultet za pastoralnu delatnost $i$ \\ pedagoške nauke, Katedra za islamsko versko obrazovanje, Jogjakarta, Indonezija \\ ${ }^{d}$ Državni islamski univerzitet $u$ Tulungagungu - Fakultet za izučavanje principa vere, adab \\ i misionarsko delovanje, Katedra za akidu i islamsku filozofiju, Tulungagung, Indonezija \\ ${ }^{e}$ Državni univerzitet u Jogjakarti - Poslediplomske studije, Katedra za pedagoške nauke, \\ Odeljenje za fiziku, Jogjakarta, Indonezija
}

Uvod: Deci sa autizmom obezbeđuje se važno versko obrazovanje. Cilj: Ovo istraživanje ima za cilj analizu iskustava nastavnika u primeni islamskih strategija verskog učenja (ISVU) kod dece sa autizmom. Metode: Ovo istraživanje je kvalitativno sa fenomenološkim pristupom. Ispitanici u ovom istraživanju bili su šest islamskih veroučitelja iz dve specijalne škole u Jogjakarti, koji su selektovani tehnikom namernog uzorkovanja. Tehnike prikupljanja podataka bili su dubinski intervjui i metode posmatranja. Analiza podataka zasnovana je na metodi analize kodiranja sa fazama organizacije podataka, čitanjem podataka, kodiranjem podataka, određivanjem i povezivanjem tema sa opisima i tumačenjem podataka. Rezultati: Rezultati istraživanja otkrili su da ISVU za decu sa autizmom prolazi kroz tri faze, i to planiranje, implementacija i evaluacija. Planiranje se vrši kako bi se utvrdila priprema koja se mora obaviti pre procesa učenja. Implementacija učenja uključuje čitanje i pisanje, kao i objašnjavanje gradiva. Evaluacija se vrši kako bi se utvrdio stepen uspešnosti sprovedenog procesa učenja. ISVU koje su izvodili nastavnici uključuju dvosmernu komunikaciju, adekvatno iskustvo i inovativne veštine. Zaključak: Očekuje se da će strategije biti dalje poboljšane kako bi se smanjile prepreke u učenju.

Ključne reči: autizam, iskustvo, islam, nastavne veštine

RECEIVED: 11.10 .2020

ACCEPTED: 16.12 .2020 . 